\title{
PENGGUNAAN MEDIA PLAYDOUGH/PLASTISIN UNTUK MENGEMBANGKAN KREATIVITAS ANAK USIA 4-5 TAHUN DI TK BINA CERDAS DESA RUNGGU KECAMATAN BELO
}

\author{
Endang, Syafrudin \\ Email:
}

\section{ABSTRAK}

Penggunaan Media Playdough/Plastisin Untuk Mengembangkan Kreativitas Anak Usia 4-5 Tahun di TK Bina Cerdas Desa Runggu Kecamatan Belo. Tujuan penelitian ini adalah untuk mengembangkan kreatifitas anak usia 4-5 Tahun yang belum berkembang secara optimal di Pendidikan Anak Taman Kanak-Kanak (TK) Bina Cerdas Desa Runggu Kecamatan Belo yang berjumlah 35 anak. Metode yang digunakan dalam penelitian ini adalah penelitian tindakan kelas yang terdiri dari tiga siklus melalui langkah-langkah perencanaan, tindakan, observasi dan refleksi. Teknik pengumpulan data melalui observasi dan dokumentasi. Instrumen yang digunakan adalah lembar observasi (chek list). Teknik analisis data menggunakan trianggulasi. Hasil penelitian yang diperoleh menunjukkan bahwa upaya guru dalam mengembangkan kretivitas dengan menggunakan media playdough pada Anak Usia Dini; Memberikan semangat, Memberikan pujian-pujian, Memicu anak untuk berinspirasi. Mendukung bakat anak dan mengikut sertakan dalam lomba sesuai bakat anak, agar anak tetap percaya diri, aktif dan berani tampil. Manfaat palydough sebagai upaya meningkatkan kreatifitas anak. Hasil Penelitian dapat diuraikan bahwa faktor penghambat dalam mengembangkan kreativitas pada anak adalah sebagai berikut; Anak terlalu di paksa untuk terus latihan sehingga anak tersebut bosan, Ibu terlalu memaksa anak mendapatkan juara sehingga anak merasa terlalu tertekan. Berdasarkan penelitian tersebut dapat direkomendasikan bahwa melalui media playdough/plastisin sangat efektif untuk mengembangkan kreatifitas anak.

Kata Kunci: Mengembangkan Kreatifitas, Media Playdough/Plastisin. 


\section{PENDAHULUAN}

Kreativitas merupakan salah satu faktor yang memiliki peran penting dalam kehidupan. Melalui kreativitas, anak dapat berkreasi sesuai dengan bakat ataupun kemampuannya dan dapat memecahkan suatu permasalahan serta dapat meningkatkan kualitas hidupnya di masa yang akan datang. Kreativitas dapat memberi anak kesenangan dan kepuasan pribadi yang sangat besar, penghargaan yang mempunyai pengaruh nyata terhadap perkembangan kepribadiannya. Pada dasarnya anak telah mempunyai potensi kreatif dalam dirinya sejak lahir. Namun perlu adanya stimulus kembali lewat lingkungan sehingga perkembangan kreativitas dapat meningkat. ${ }^{1}$

Kreativitas seorang anak berawal dari rasa ingin tahunya yang besar. Bakat kreatif tersebut dimiliki oleh semua orang tanpa terkecuali dan bakat tersebut dapat ditingkatkan jika diasah sejak dini. Namun jika bakat kreatif tersebut tidak diasah maka bakat itu tidak akan dapat berkembang bahkan akan menjadi bakat terpendam yang tidak dapat diwujudkan. Masa anak adalah masa belajar yang potensial. Usia dini merupakan masa yang sering disebut "golden age". Dikatakan golden age sebab pada usia ini tingkat pertumbuhan dan perkembangan anak sangat cepat. Dengan demikian pada saat inilah anak membutuhkan stimulus yang baik agar pertumbuhan dan perkembangan anak dapat berkembang sesuai dengan tahap perkembangannya. Namun, pengembangan kemampuan kreativitas anak di Indonesia masih belum optimal. ${ }^{2}$ Hal tersebut terbukti dengan hasil penelitian yang dilakukan oleh Jellen dan Urban yang menunjukkan bahwa Indonesia menempati posisi terendah dibandingkan 8 negara lainnya yaitu jauh dibawah Filipina, Amerika Serikat, Inggris dan Jerman, India, Kamerun dan Zulu.

Perkembangan kreativitas pada anak akan berkembang secara optimal jika diberikan stimulus yang tepat. Setiap kegiatan anak harus dibuat menyenangkan, menarik perhatian anak, dan membuat nyaman anak agar setiap proses menjadi lebih efektif. Salah satu metode yang dapat memberikan kesenangan anak dan membuatnya menjadi kreatif adalah dengan bermain. Pada dasarnya anak sudah memiliki potensi kreatif sejak lahir ke dunia ini.

Secara alamiah perkembangan anak berbeda-beda, baik dalam

Jurnal Pelangi Jurnal pemikiran dan penelitian pendidkan Islam anak Usia Dini 
bakat, minat, kreativitas, kematangan emosi, kepribadian, keadaan jasmani, dan sosialnya. Setiap anak lahir dengan potensi kreatif walaupun tingkatannya berbeda-beda dan memiliki kemampuan tidak terbatas dalam belajar yang telah ada dalam dirinya untuk dapat berpikir kreatif, produktif, dan dapat dikembangkan. Kreativitas seorang anak terlihat dari rasa ingin tahunya yang besar. Bakat kreatif tersebut dimiliki oleh semua orang tanpa kecuali dan yang lebih penting lagi bakat dapat ditingkatkan jika dipupuk sejak dini. Jika bakat kreatif tersebut tidak dipupuk maka bakat tersebut tidak akan berkembang bahkan menjadi bakat terpendam yang tidak dapat diwujudkan. ${ }^{3}$

Kreativitas memiliki peran yang sangat penting dalam kehidupan anak. Melalui kreativitas, anak dapat berkreasi sesuai dengan bakat ataupun kemampuan, anak dapat memecahkan masalah dan dapat meningkatkan kualitas hidupnya di masa yang akan datang. Pengembangan kreativitas pada anak prasekolah atau usia dini merupakan tujuan terpenting yang mesti diakomodasikan melalui kurikulum, karena anak yang kreatif akan mampu mengaplikasikan kemampuan kognitif, afektif dan psikomotornya secara lebih luas, melalui berbagai gagasan, untuk kemampuan atau keterampilan, produk benda atau bentuk pertanyaan-pertanyaan. Dalam bermain anak memiliki nilai kesempatan untuk mengekspresikan sesuatu yang dirasakan dan dipikirkan, dengan bermain, anak sebenarnya sedang mempraktekkan keterampilan dan anak mendapatkan kepuasan dalam bermain, yang berarti mengembangkan dirinya sendiri. ${ }^{4}$ Anak dapat mengembangkan otot kasar dan halus, dapat meningkatkan penalaran, dan memahami keberadaan lingkungannya, membentuk daya imajinasi, daya fantasi, dan kreativitas dengan bermain. Salah satunya melalui permainan playdough/plastisin.

Playdough/Plastisin merupakan mainan dari lilin yang dapat diubahubah bentuknya, namun untuk membuatnya sendiri tidak menggunakan lilin tetapi dapat diganti dengan bahan lain seperti misalnya tanah liat, playdough/plastisin dan adonan kue. Permainan playdough/plastisin memerlukan kelenturan motorik halus anak. Permainan ini sangat

${ }^{3}$ Ibid, ...hal.44-45.

${ }^{4}$ Utami Munandar, Mengembangkan Bakat Dan Kreativitas Anak Sekolah Petunjuk Bagi Para Guru dan Orangtua, (Jakarta: Grasindo, 2014), hal.13. 
sederhana dan tidak mahal, karena dapat dibuat sendiri dari bahan yang sederhana dan mudah didapat. Bermain playdough//plastisin adalah salah satu aktivitas yang bermanfaat untuk perkembangan otak anak, dengan bermain playdough//plastisin anak tak hanya memperoleh kesenangan, tapi juga bermanfaat untuk meningkatkan perkembangan otak, motorik halus dan kasar anak. Permainan playdough/plastisin adalah permainan yang tanpa aturan sehingga berguna untuk mengembangkan kemampuan imajinasi dan kreativitas anak. Bermain playdough/plastisin dapat meningkatkan rasa ingin tahu anak, sekaligus mengajarkannya tentang problem solving yang berguna untuk meningkatkan kemampuan

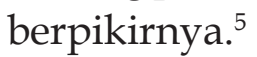

"Umi Kayvan mengungkapkan bahwa pengembangan kreativitas dapat dilakukan melalui menciptakan produk salah satunya adalah dengan media Playdough/Plastisin. Definisi tentang Playdough/ Plastisin yaitu suatu bahan yang lembut, dapat membuat anak-anak terdiam cukup lama ketika mengerjakannya, warnanya pun bermacammacam (seperti warna pelangi) tetapi bahannya mudah rapuh dan kotorannya dapat menempel pada karpet" ${ }^{6}$

Media playdough/plastisin merupakan salah satu alat permainan edukatif karena dapatmendorong imajinasi anak. Media playdough/plastisin ini akan membuat anak suka berkreasi sehingga dapat mengembangkan kreativitasnya. Anak dilatih menggunakan imajinasi untuk membuat atau menciptakan suatu bangunan atau benda sesuai dengan khayalannya seperti angka, gedung, huruf, abjad, dan binatang, dan lain-lain.

Playdough/palstisin adalah adonan mainan yang merupakan bentuk modern dari mainan tanah liat. Playdough/plastisin mudah dimainkan dan disukai oleh balita dan anak-anak. Dengan menggunakan playdough/ plastisin anak usia 4-5 tahun dapat mengekspresikan kreativitas anak. ${ }^{7}$

Berdasarkan hasil observasi awal di TK Bina Cerdas Desa Runggu Kecematan Belo, masih banyak anak yang belum mengerti tentang bagaimana cara membuat playdough/plastisin itu sendiri. Maka dengan demikian peneliti mencoba membuat produk yang bahan dasarnya terbuat dari lilin. Tujuannya agar anak-anak kreatif dalam membuat

\footnotetext{
${ }^{5}$ Ibid,...hal.14-15.

${ }^{6}$ Chintia Monica, Buku Kreativitas Anak, (Jakarta: Bintang Indonesia, 2015), hal.26.

${ }^{7} \mathrm{Ibid}, .$. hal.27-28.
}

Jurnal Pelang̉i Jurnal pemikiran dan penelitian pendidkan Islam anak Usia Dini 
barang apa saja yang mereka inginkan. Sehingga perkembangan kreativitas anak dapat berkembang secara optimal dan lebih baik.

Kreativitas perlu dikembangkan pada anak, sebab dengan kreativitas dapat melahirkan generasi yang cerdas, kreatif, mandiri, dan berkepribadian dengan adanya media alat permainan edukatif. Berdasarkan uraian yang telah dipaparkan di atas, maka peneliti melakukan pengkajian mendalam tentang bagaimana "Penggunaan Media Playdough/Plastisin Untuk Mengembangkan Kreativitas Anak Usia 4-5 Tahun di TK Bina Cerdas Desa Runggu Kecamatan Belo."

\section{Media Pembelajaran}

\section{Pengertian Media Pembelajaran}

Media merupakan bentuk jamak dari kata medium. Dalam ilmu komunikasi, media bisa diartikan sebagai saluran, sarana penghubung, dan ala-alat komunikasi. Kalimat media sebenarnya berasal dari bahasa latin yang secara harafiah mempunyai arti perantara atau pengantar. Media adalah sebagai suatu alat dimana otak sebuah kaum menanamkan ideologinya dalam wacana yang kemudian diproduksi oleh media, kemudian dikonsumsi oleh masyarakat. ${ }^{8}$

Menurut Association for Education and Communication Technology (AECT), dalam fadillah Media didefinisikan sebagai segala bentuk yang dipergunakan untuk suatu proses penyaluran informasi. Sedangkan Education Association (NEA), mengartikan Media sebagai benda yang dapat dimanipulasi, dilihat, didengar, dibaca atau dibicarakan beserta instrumen yang dipergunakan, baik dalam kegiatan belajar mengajar yang dapat mempengaruhi aktifitas program instruksional. ${ }^{9}$

Brigs dalam Abuddinata berpendapat bahwa media adalah segala alat fisik yang dapat menyajikan pesan serta merangsang siswa untuk belajar, seperti buku, film, kaset, dan sebagainya. Dan ada pula yang berpendapat bahwa, media adalah alat, metode dan teknik yang digunakan dalam rangka mengaktifkan komunikasi dan interaksi antara

${ }^{8}$ Eni Maryani, Media dan Perubahan Sosial, (Bandung: Rosdakarya, 2011), Cet Ke-1, hal.17.

${ }^{9}$ Muhammad Fadlillah, Desain Pembelajaran Paud Tinjauan Teoritik dan Praktik, (Yogyakarta:ArRuzz Media, cetakan 1, 2012), hal.205-206. 
guru dan siswa dalam proses pendidikan dan pengajaran disekolah. ${ }^{10}$

Menurut Gerlach dan Ely yang dikutip oleh Azhar Arsyad, media apabila dipahami secara garis besar adalah manusia, materi dan kejadian yang membangun kondisi yang membuat siswa mampu memperoleh pengetahuan, keterampilan atau sikap. Dalam pengertian ini guru, buku teks, dan lingkungan sekolah merupakan media. Sedangkan menurut Wina Sanjaya media adalah seluruh alat atau bahan yang dapat dipakai untuk mencapai tujuan pendidikan seperti radio, televisi, buku, koran, majalah, dan sebagainya. ${ }^{11}$

Berdasarkan paparan diatas, dapat disimpulkan bahwa media adalah alat bantu yang dapat dijadikan sebagai penyalur pesan dari seorang pendidik kepada peserta didik, guna untuk mencapai tujuan pengajaran. Dengan kata lain, media adalah jembatan informasi yang digunakan oleh seorang guru dalam pembelajaran, sehingga memudahkan peserta didik dalam memahami dan mengerti proses pembelajaran.

Media pembelajaran adalah sarana penyampaian pesan pembelajaran kaitannya dengan model pembelajaran langsung yaitu dengan cara guru berperan sebagai penyampai informasi dan dalam hal ini guru seyogyanya menggunakan berbagai media yang sesuai. Media pembelajaran adalah alat bantu proses belajar mengajar. Segala sesuatu yang dapat dipergunakan untuk merangsang pikiran, perasaan, perhatian dan kemampuan atau ketrampilan pebelajar sehingga dapat mendorong terjadinya proses belajar.

\section{Manfaat Media Pembelajaran}

Adapun manfaat media pembelajaran bagi pengajar, yaitu sebagai berikut; ${ }^{12}$

1). Memberikan pedoman, arah untuk mencapai tujuan.

2). Menjelaskan struktur dan urutan pengajaran.

3). Memberikan kerangka sistematis secara baik.

${ }^{10}$ Abuddin Nata, Perspektif Islam Tentang Strategi Pembelajaran, ( Jakarta:Charisma Putra Utama Cetakan ke 3, 2014), hal.296.

${ }^{11}$ Wina Sanjaya, Strategi Pembelajaran Berorientasi Standar Proses Pendidikan, (Jakarta: Prenada Media Group, 2010), hal.163.

${ }^{12}$ Azhar Arsyad, Media Pembelajaran, (Bandung: PT Rosdakarya, 2014), hal.5-6.

Jurnal Pelang̉i Jurnal pemikiran dan penelitian pendidkan Islam anak Usia Dini 
4). Memudahkan kembali pengajar terhadap materi pembelajaran.

5). Membangkitkan rasa percaya diri seorang pengajar.

6). Meningkatkan kualitas pembelajaran.

\section{Playdough/Plastisin}

\section{Pengertian Playdough/Plastisin}

Playdough/Plastisin dilihat dari arti kata di dalam kamus Bahasa Inggris Play adalah bermain dan dough adalah adonan, jadi Playdough/ Plastisin adalah bermain melalui adonan. Adonan tersebut terdiri dari bahan-bahan seperti terigu, garam, soda kue, sabun cair, pewarna hijau dan merah. ${ }^{13}$

"Einon dalam Fadia Syakira mengemukakan bahwa 'Playdough is a soft, squidgy material that can keep children occupled for considerable lengths of time. Although it is available in a rainbowof colours, it inevitably ends up as grey crumbly mess, or alternatively, a smudge on the carpet."14

Uraian diatas dapat diartikan bahwa playdough/plastisin adalah suatu bahan yang lembut, dapat membuat anak-anak terdiam cukup lama ketika mengerjakannya, warnanyapun bermacam-macam seperti warna pelangi, tetapi bahannya mudah rapuh dan kotorannya dapat menempel pada karpet. ${ }^{15}$

Playdough/Plastisin memiliki nilai ekonomis dan keamanan untuk digunakan dalam pembelajaran usia dini. Nilai fleksibilitas menunjukkan bahwa penggunaan alat permainan atau media playdough/plastisin memberikan kesempatan yang seluas-luasnya dalam membentuk pola yang diinginkan sesuai dengan imajinasi anak, karena sifat dari playdough/plastisin sangat mudah untuk dibentuk apapun. ${ }^{16}$

\section{Manfaat Playdough/Plastisin}

Bermain dengan playdough/plastisin sangat bermanfaat untuk melatih kreativitas dan daya imajinasi seorang anak. Guru yang kreatif dapat

\footnotetext{
${ }^{13}$ Dorothy Einon, Creative Child (Anak Kreatif), (Jakarta: Pustaka Press, 2008), hal.36.

${ }^{14}$ Fadia Syakira, Cara Membuat Playdough dengan Mudah, (Bandung:Rosdakarya, 2015), hal.10.

${ }^{15}$ Ibid., hal.37.

${ }^{16}$ Dwirosanty, Manfaat Playdough, www.associatedcontent.com/article, diakses pada hari kamis tanggal 12 bulan 10 tahun 2017 jam 12:00 WIB.
} 
membuat sendiri disekolah, dan dapat mengajak anak didiknya untuk bersama-sama membuat adonannya, karena dalam proses pembuatannya adonan dapat menjadi pengalaman tersendiri bagi anak. Guru bisa mengenalkan berbagai macam konsep melalui playdough/plastisin, antara lain; tekstur, warna, ukuran, simbol, serta dapat merangsang kreativitas anak berlatih untuk menciptakan sesuatu.

Sejalan dengan hal diatas, Einon Dorothy menyatakan beberapa manfaat apabila anak bermain dengan menggunakan media playdough/ plastisin, yaitu; ${ }^{17}$

1) Anak dengan mudah bermain sendiri dan membuat hasil yang memuaskan.

2) Meningkatkan rasa percaya diri pada anak.

3) Playdough/plastisin menyediakan banyak cara untuk suatu aktivitas.

4) Anak dapat duduk diam dan memfokuskan pada pemanfatan media playdough/plastisin.

Selain itu media playdough/plastisin ini juga memiliki sejumlah manfaat, antara lain dapat membantu anak;

1) Memperkuat jari-jemari, tangan dan pergelangan tangan.

2) Mengembangkan imajinasi anak.

3) Mengembangkan harga diri, tidak benar dan salah serta anak memiliki kesempatan untuk mendapatkan penguasaan atas lingkungan mereka.

4) Melepaskan perasaan tegang atau marah.

5) Playdough/plastisin dapat dijadikan bentuk apa saja. ${ }^{18}$

Dari uraian diatas, dapat disimpulkan bahwa manfaat dari penggunaan media Playdough/Platisin adalah sebagai berikut;

1) Mengembangkan kemampuan motorik halus, agar anak bisa terstimulasi.

2) Anak dapat belajar mengenal tekstur.

3) Anak dapat mengembangkan mainan menggunakan simbol atau mainan tiruan.

4) Mengembangkan koordinasi motorik halus (meremas, membuat sesuatu, membentuk). ${ }^{19}$

${ }^{17}$ Dorothy Einon, Creative Child (Anak Kreatif), (Jakarta: Pustaka Press, 2008), hal.38.

${ }^{18} \mathrm{Ibid}, \ldots .$. hal.39.40.

${ }^{19}$ Yusep Nur Jatmika, Ragam Aktivitas Harian untuk Playgroup (Yogyakarta: DIVA Press, 2012), hlm 85.

Jurnal Pelang̉i Jurnal pemikiran dan penelitian pendidkan Islam anak Usia Dini 


\section{Ciri-ciri Media Playdough/Plastisin}

Playdough/plastisin termasuk ke dalam alat permainan edukatif untuk Anak Usia Dini, karena media playdough/plastisin ini mempunyai ciri-ciri sebagai berikut; (1) ditunjukkan untuk Anak Usia Dini, (2) berfungsi untuk mengembangkan aspek-aspek perkembangan, (3) dapat digunakan dengan berbagai cara, bentuk, serta multiguna, (4) aman dan tidak berbahaya bagi anak, (4) dirancang untuk mendorong aktivitas dan kreativitas, (6) mengandung nilai pendidikan. ${ }^{20}$

\section{Aspek-Aspek yang dapat dikembangkan Melalui Permainan Media Playdough/Plastisin}

Playdough/plastisin memiliki peran terhadap aspek-aspek perkembangan antara lain;

1). Perkembangan Motorik

Penggunaan media playdough/plastisin dapat membantu anak melatih keterampilan fisik dengan tangan, ketika mereka memanipulasi playdough/plastisin dengan jari-jari mereka. Anak dapat berlatih keterampilan seperti mencubit, meremas atau menyodok saat mereka bermain dengan playdough/plastisin.

2). Perkembangan Kognitif

Penggunaan media playdough/plastisin dapat membantu anak dalam melatih imajinasi dan kemampuan kognitif lainnya seperti imitasi, simbolisme, dan pemecahan masalah. Hal ini dapat membantu anak belajar lebih banyak tentang lingkungan saat anak membuat dan meniru benda sehari-hari dengan bermain playdough/plastisin.

3). Perkembangan Emosi

Penggunaan media playdough/plastisin dapat membantu anak untuk tenang disaat frustasi atau marah. Memegang dan meremas adonan saat bermain dapat menghasilkan efek menenangkan pada diri anak dan berguna untuk mengajarkan keterampilan manajemen kemarahan. Selain itu, anak mungkin merasa lebih nyaman untuk mengekspresikan diri.

4). Perkembangan Sosial

\footnotetext{
${ }^{20}$ Taufan, Permainan Playdough, www.albalitacerdas.com., diakses pada hari kamis tanggal 12 bulan 10 tahun 2017 jam 12:02 WIB.
} 
Penggunaan media playdough/plastisin dapat membantu anak mengembangkan keterampilan sosial saat ia bermain bersama dengan anak-anak yang lain. Selain itu, bermain playdough/plastisin memberikan kesempatan bagi anak untuk melatih dalam bekerja sama dan berbagi.

5). Perkembangan Bahasa

Gunakanlah kata-kata untuk mendeskripsikan kegiatan anak-anak disaat bermain playdough/plastisin. Atau jika perlu berilah nama untuk setiap bentuk yang anak buat dari playdough/plastisin. ${ }^{21}$

\section{Kelebihan dan Kelemahan Playdough/Plastisin}

Menurut Dwijunianto bahwa, media playdough/plastisin memiliki kelebihan dan kelemahan antara lain; kelebihan playdough/plastisin ialah (1) memberikan pengalaman secara langsung dan kongkrit, (2) tidak adanya verbalisme, (3) obyek dapat ditunjukkan secara utuh baik konstruksinya atau cara kerjanya dari segi struktur organisasi dan alur proses secara jelas. ${ }^{22}$ Sedangkan kelemahan playdough/plastisin ialah (1) tidak dapat membuat objek yang besar karena membutuhkan ruang besar (2) perawatannya rumit. ${ }^{23}$

\section{Cara Membuat Playdough/Plastisin}

Sebelum mulai membuat playdough/plastisin, guru terlebih dahulu memberi pengertian bahwa, playdough/plastisin bukanlah makanan, melainkan alat yang dibuat itu hanya untuk mainan.

Adapun bahan-bahan yang diperlukan untuk membuat playdough/ plastisin adalah sebagai berikut; a) tepung terigu, b) air, c) garam, d) Minyak sayur, e) pewarna makanan. Berikut disajikan bahan-bahan yang diperlukan untuk membuat playdough/plastisin.

\section{Gambar 1}

\footnotetext{
${ }^{21}$ Pujianto, Media Belajar Plastisin, http://dwijunianto.wordpress.com/mediabelajar-plastisin, diakses pada hari rabu tanggal 11bulan 10 tahun 2017 jam 11:25 WIB.

${ }^{22}$ Dwijunianto, Media Belajar Plastisin, http://dwijunianto.wordpress.com/mediabelajar-plastisin, diakses pada hari rabu tanggal 11bulan 10 tahun 2017 jam 12:20 WIB.

${ }^{23}$ Bk 2009, Belajar Dengan Lilin Plastin, Http:/ / Bk2009.Wordpress.Com/2010/11/30/ Belajardengan-Lilin-Plastisinkel, diakses pada hari rabu tanggal 11bulan 10 tahun 2017 jam 12:25 WIB.
}

Jurnal Pelang̉i Jurnal pemikiran dan penelitian pendidkan Islam anak Usia Dini 


\section{Bahan-bahan untuk membuat Playdough/Plastisin}

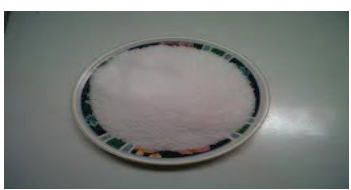

Garam

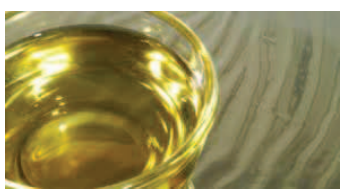

Minyak Sayur

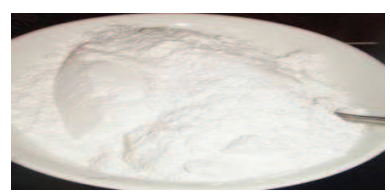

Tepung Terigu

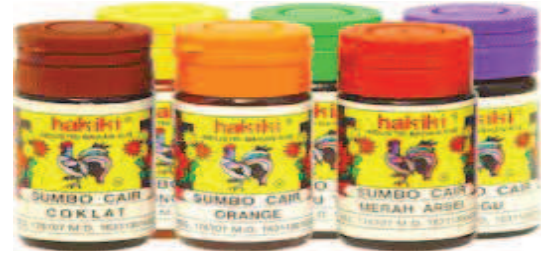

Pewarna Makanan

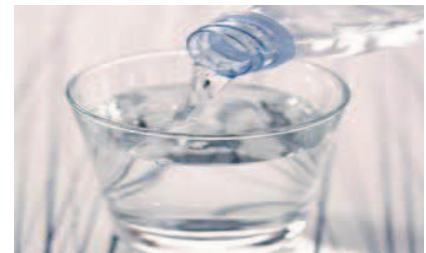

Air Putih

Sedangkan peralatan yang digunakan sebagai berikut; a) sendok, b) cangkir plastik, c) celemek, d) baskom plastik, e) wadah untuk menyimpan hasil. Berikut disajikan gambar peralatan yang digunakan untuk membuat playdough/plastisin ${ }^{24}$

\section{Gambar 2}

Peralatan yang digunakan

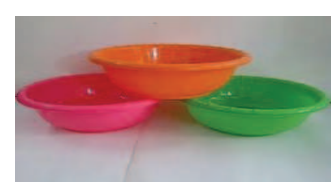

Baskom

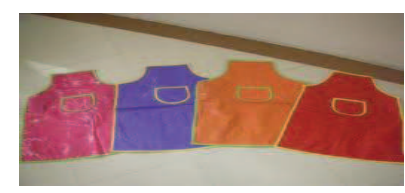

Celemek

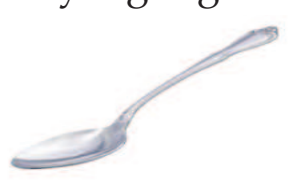

Sendok

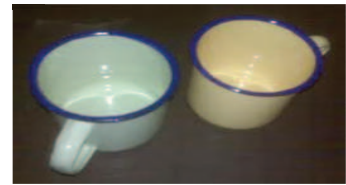

Cangkir plastik

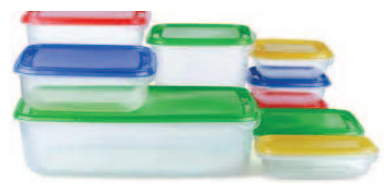

Wadah plastik

Cara pembuatan Playdough/Plastisin sebagai berikut;

1) Siapkan peralatan dan bahan-bahan playdough/plastisin.

2) Kemudian masukan dua cangkir tepung terigu dan satu cangkir garam kedalam baskom, kemudian diaduk rata, setelah tercampur

${ }^{24}$ Dwirosanty, Bikin Playdough Sendiri, www.associatedcontent.com/article., diakses pada hari kamis tanggal 12 bulan 10 tahun 2017 jam 12:00 WIB. 
masukkan satu sendok minyak sayur dan satu cangkir air, aduk rata kembali sampai adonan kalis (tidak lengket di tangan), kemudian adonan yang sudah jadi dipisahkan menjadi beberapa bagian untuk diberi warna sesuai selera anak. Untuk pemakaian pewarna, cukup diberikan tetes saja dan bisa dicampur-campur, kemudian adonan diuleni kembali sampai warnanya merata. Setelah adonan playdough/ plastisin jadi maka anak-anak pun siap untuk membentuk apa saja sesuai tema yang diberikan guru.

Berikut ini adalah contoh playdough/plastisin yang sudah jadi dan siap dipakai.

\section{Gambar 3}

Contoh Playdough/Plastisin yang sudah jadi
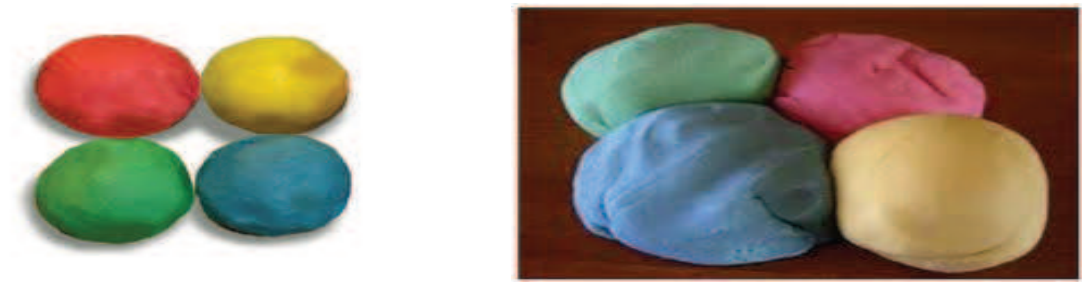

Playdough/Plastisin dapat digunakan kembali setelah anak-anak selesai bermain, masukkan dalam kotak plastik dan tutup rapat. atau bungkus dengan plastik. Lalu masukkan ke dalam lemari es, Playdough/ Plastisin pun bisa tahan sampai satu bulan. Jika adonan menjadi lengket setelah disimpan di dalam lemari es, bubuhi sedikit tepung terigu dan uleni kembali adonan hingga kalis. Jika anak sampai menelan adonan Playdough/Plastisin secara tidak sengaja tentunya akan lebih aman dan tidak perlu khwatir karena bahan-bahan yang terkandung di dalam Playdough/Plastisin dibuat sendiri bukan dari bahan kimia.

Gambar II. 4

Contoh-contoh Playdough/Plastisin yang siap pakai 

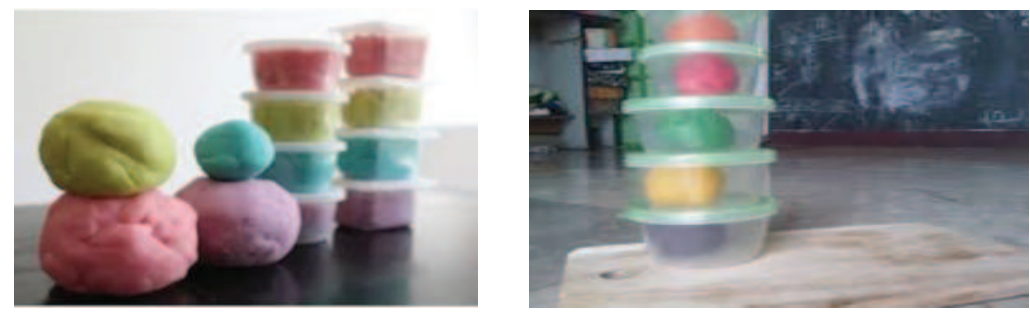

Sebagaimana hal yang telah diuraikan diatas, alat permainan playdough/plastisin dibuat dari bahan-bahan ramah lingkungan atau bahan makanan yang higenis, jika anak mencicipi pun tidak akan berbahaya asalkan kebersihannya dijaga tetapi bahan ini terlalu asin kalau dimakan. Dengan demikian mainan playdough/plastisin ini : 1) aman bagi anak; 2) tidak mengandung timbal, cat dan racun; 3) mudah dibuatnya; 4) murah; 5) anak lebih kreatif dan imajinatif. ${ }^{25}$

\section{Pengembangan Kreativitas}

\section{Pengertian Kreativitas}

Pendidikan Anak Usia Dini adalah suatu upaya pembinaan yang ditunjukkan bagi anak sejak lahir sampai dengan usia enam tahun, yang dilakukan melalui pemberian rangsangan pendidikan untuk membantu pertumbuhan dan perkembangan jasmani dan rohani agar anak memiliki kesiapan dalam memasuki pendidikan lebih lanjut.

Pendidikan Anak Usia Dini merupakan salah satu bentuk penyelenggaraan pendidikan yang menitikberatkan pada peletakan dasar ke arah pertumbuhan dan perkembangan fisik, kecerdasan, sosial emosional, bahasa dan komunikasi, sesuai dengan keunikan dan tahaptahap perkembangan anak usia dini.

Menurut Indra Soefandi, kreativitas merupakan kemampuan untuk membuat kombinasi baru berdasarkan data, informasi, atau unsur-unsur yang ada. ${ }^{26}$ Menurut Ambile dalam Ahmad Susanto sebagai berikut, "Kreativitas merupakan kualitas suatu produk atau person yang dinilai

\footnotetext{
${ }^{25}$ Well Mina, Membuat Plastisin yang Menyenangkan Sejarah Clay, http://www. scribd. com/dok /80089975/plastisin, diakses pada hari kamis tanggal 12 bulan 10 tahun 2017 jam 12:12 WIB.

${ }^{26}$ Indra Soefandi, dan S Ahmad Pramudya, Strategi Mengembangkan Potensi Kecerdasan Anak, (Jakarta:Bee Media Indonesia, 2009), hal.134.
} 
kreatif oleh pengamat yang ahli" (creativity can be regarded as the quality of products or response judge to be creative by appropriate observes). Produk baru dapat disebut karya kreatif ini jika mendapatkan pengakuan dari masyarakat pada waktu tertentu. ${ }^{27}$

Dalam kamus besar bahasa Indonesia, dijelaskan bahwa kreativitas adalah (1) kemampuan untuk mencipta daya cipta; (2) perihal berkreasi kekreatifan. ${ }^{28}$ Definisi kata kreativitas adalah pengembangan, pertumbuhan manusia, pemahaman diri, dan rehabilitasi pola pikir seseorang yang harus dipahami, pemecahan masalah yang disertai dengan ide-ide untuk melakukan sesuatu. ${ }^{29}$

Menurut bahasa, kreatif adalah menciptakan sesuatu yang baru tanpa contoh sebelumnya. Kreatif adalah kemampuan berpikir untuk mencapai produk beragam dan baru yang dapat dilaksanakan baik dalam bidang keilmuan, seni, sastra maupun lainnya. Kemampuan beraktivitas seseorang dikaitkan dengan berbagai aktivitas. Pemahaman kata kreatif dalam arti luas sering dianggap tidak penting padahal ide cemerlang dapat dikaitkan sebagai bentuk kreativitas jika itu merupakan suatu temuan baru. ${ }^{30}$

Menurut A. Chaedar Alwasilah dalam Ngainun Naim, kreativitas adalah kemampuan mewujudkan bentuk baru, struktur kognitif baru, produk baru, yang mungkin bersifat fisikal seperti teknologi atau bersifat simbolik dan abstrak seperti rumus, karya sastra, atau lukisan. ${ }^{31}$ Berkreasi adalah memunculkan kejutan efektif yang misterius, karena datangnya ilham atau solusi yang begitu cepat, tepat waktu, dan tidak dipaksakan. ${ }^{32}$

Dari beberapa definisi diatas dapat dikemukakan bahwa kreativitas merupakan kemampuan seseorang untuk melahirkan sesuatu yang baru, baik berupa gagasan maupun karya nyata, baik dalam karya baru

\footnotetext{
${ }^{27}$ Ahmad Susanto, Perkembangan Anak Usia Dini Pengantar dalam Berbagai Aspeknya, (Jakarta: Kencana, 2011), hal.113.

${ }^{28}$ Departemen Pendidikan Nasional, Kamus Besar Bahasa Indonesia; Edisi Ketiga, (Jakarta: Balai Pustaka,2005), hal. 599.

${ }^{29}$ Tut sayogya, Creative Mind, (Jakarta: Elex Media Komputindo, 2008), hal.65.

${ }^{30} \mathrm{Ibid} ., \mathrm{hlm} 67$.

${ }^{31}$ Ngainum Naim, Menjadi Guru Inspiratif, (Yogyakarta: Pustaka Pelajar, 2009), hal.245.

${ }^{32}$ Slameto, Belajar dan Faktor-faktor yang Mempengaruhinya, (Jakarta: PT Rineka Cipta, 2003), hal.138.
}

Jurnal Pelang̉i Jurnal pemikiran dan penelitian pendidkan Islam anak Usia Dini 
maupun kombinasi dengan hal-hal yang sudah ada, yang semuanya itu berbeda dengan apa yang telah ada sebelumnya.

Kreativitas pada anak di taman kanak-kanak ditampilkan dalam berbagai bentuk, baik dalam mengembangkan kreativitas melalui bermain playdough/plastisin, bercerita dan bernyanyi. Kreativitas sangat penting dalam kehidupan, dengan kreativitas akan mendorong anak untuk mencoba bermacam cara dalam melakukan sesuatu yang mereka senangi.

\section{Aspek-aspek yang Mempengaruhi Kreativitas}

Adapun aspek-aspek yang mempengaruhi kreativitas, seperti di bawah ini;

a) Aspek Kemampuan Kognitif

Kemampuan kognitif (kemampuan berpikir) yang dapat mengembangkan kreativitas adalah kemampuan berpikir secara divergen, yaitu kemampuan untuk memikirkan berbagai alternatif pemecahan suatu masalah.

b) Aspek Intuisi dan Imajinasi

Intuisi dan imajinatif merupakan aspek yang mempengaruhi munculnya kreativitas karena kreativitas berkaitan dengan aktivitas belahan otak kanan.

c) Aspek Penginderaan

Kepekaan dalam penginderaan ini menyebabkan seseorang dapat menemukan sesuatu yang tidak dapat dilihat atau dipikirkan oleh orang lain.

d) Aspek Kecerdasan Emosi

Kecerdasan emosi adalah aspek yang berkaitan dengan keuletan, kesabaran, dan ketabahan dalam menghadapi ketidakpastian dan berbagai masalah yang berkaitan dengan kreativitas. ${ }^{33}$

\section{Ciri-Ciri Kreativitas}

Menurut Sumanto anak yang kreatif cirinya yaitu punya kemampuan berfikir kritis, ingin tahu, tertarik pada kegiatan/tugas yang dirasakan

\footnotetext{
${ }^{33}$ Martini Jamaris, Perkembangan dan Pengembangan Anak Usia Taman Kanak-kanak, (Jakarta: PT Gramedia Widiasarana Indonesia, 2006), hal.66.
} 
sebagai tantangan, berani mengambil resiko, tidak mudah putus asa, menghargai keindahan, mampu berbuat atau berkarya, menghargai diri sendiri dan orang lain. ${ }^{34}$

Sementara, Sund dalam Nursisto menyatakan bahwa individu dengan potensi kreatif dapat dikenal secara mudah melalui pengamatan ciri-ciri yang dimiliki terutama dalam setiap pertemuan atau diskusi, ciri-ciri tersebut, antara lain: ${ }^{35}$

a. Mempunyai hasrat ingin mengetahui

b. Bersikap terbuka terhadap pengalaman baru

c. Panjang akal

d. Keinginan untuk menemukan dan meneliti

e. Cenderung lebih suka melakukan tugas yang lebih berat dan sulit. ${ }^{36}$

\section{Faktor-Faktor yang Mempengaruhi Kreativitas Anak}

Hasil penelitian beberapa ahli menunjukkan bahwa faktor yang mempengaruhi kreativitas meliputi: daya imajinasi, rasa ingin tahu dan orisinalitas (kemampuan menciptakan sesuatu yang baru dan tidak biasa) dapat mengimbangi kekurangan dalam daya ingat, daya tangkap, penalaran, pemahaman terhadap tugas dan faktor lain dalam intelegensi.

Kreativitas perlu dicari/dilatih oleh pendidik dan orang tua, setiap anak pada dasarnya memiliki potensi akan kreativitasnya. Oleh karena itu pendidik atau orang tua harus bisa meningkatkan kreativitas dengan melakukan pengamatan dan penilaian secara terus menerus dan berkesinambungan sebagai alat pemantau keefektifan kemampuan berkreativitas. ${ }^{37}$

${ }^{34}$ Sumanto, Pengembangan Kreativitas Seni Rupa Anak TK, (Jakarta: Diretur Pembinaan Pendidikan Tenaga Kependidikan dan Ketenagaan Perguruan Tinggi, 2005), hal.39.

${ }^{35}$ Nursisto, Kiat Menggali Kreativitas, (Yogyakarta: Mitra Gama Widya,1999), hal.35.

${ }^{36}$ Utami Munandar, Pengembangan Kreativitas Anak Berbakat (Jakarta: PT. Rineka Cipta, 2004), hal.13.

${ }^{37}$ Montolalu,B.E.F, Bermain dan Permainan Anak, (Jakarta: Universitas Terbuka, 2009), hal.26.

Jurnal Pelang̉i Jurnal pemikiran dan penelitian pendidkan Islam anak Usia Dini 


\section{Menumbuhkan dan Mengembangkan Kreativitas}

Usia prasekolah adalah suatu masa katika anak belum memasuki pendidikan formal. Oleh sebab itu, pada rentang usia dini adalah saat yang tepat untuk mengembangkan potensi dan kecerdasan anak. Pengembangan potensi anak secara terarah pada rentang usia tersebut akan berdampak pada kehidupannya di masa depan. Tetapi sebaliknya, jika orang tua tidak dapat memperhatikan pengembangan potensi anak secara benar dan terarah, bisa jadi akan berakibat fatal terhadap potensi anak yang sebenarnya. ${ }^{38}$ Kreativitas anak dapat dirangsang oleh orangtua dengan membiasakan mereka menghayati permasalahan yang timbul di dalam keluarga atau masyarakat. ${ }^{39}$ Sehingga akan muncul keinginan anak ikut serta mengatasi atau menyelesaikannya.

Grubb dalam Virzara Auryn mengemukakan bahwa para orangtua yang suka mengajari berbagai hal kepada anak-anak mereka, cenderung mempunyai anak yang kurang kreatif, dan yang perlu diperhatikan adalah kadang orangtua terlalu berlebihan mencoba untuk terlibat dalam proses kreativitas anak sehingga anak tersebut mengalami keterlambatan dalam mengembangkan kreativitasnya. ${ }^{40}$

Rhodes dalam Yuliani Nuraini Sujiono menjelaskan bahwa pengembangan kreativitasnya pada diri seseorang dapat dilakukan melalui pendekatan $4 \mathrm{P}$, yaitu person (pribadi), di mana tindakan kreatif muncul dari keunikan keseluruhan kepribadian dalam interaksi dengan lingkungan; process (proses), di mana langkah-langkah proses kreatif dimulai dari tahap persiapan, inkubasi, iluminasi, dan verifikasi; press (dorongan), berupa dorongan internal dan eksternal dari lingkungan sosial dan psikologis; dan product (hasil akhir) yang ditandai dengan orisinalitas, kebaruan, kebermaknaan dan teramati. ${ }^{41}$

Menurut Wallas dalam Indra Soefandi, ada empat tahapan yang harus dilalui agar kreativitas dapat dikembangkan pada diri anak, yaitu;

a) Tahap persiapan, yaitu tahap pengumpulan informasi atau data yang diperlukan untuk memecahkan suatu masalah.

b) Tahap inkubasi, yaitu tahap di mana individu seakan-akan melepaskan diri untuk sementara dari masalah-masalah tersebut dan menyimpannya dalam alam bawasadarnya.

c) Tahap iluminasi, yaitu timbulnya inspirasi atau gagasan baru. 
d) Tahap verifikasi, yaitu tahap di mana ide atau kreasi baru tersebut harus diuji dengan realitas yang ada. ${ }^{42}$

Untuk mengembangkan kreativitas anak, orang tua atau guru harus dapat menyediakan suatu lingkungan yang kaya dengan stimulus, motivasi, dorongan, serta bimbingan dan dapat menciptakan suatu kondisi di mana anak mendapatkan sebuah respons yang positif secara beruntun untuk setiap perilakunya, yang tentunya akan melahirkan sesuatu yang orisinal. Cara-cara yang dilakukan antara lain; ${ }^{43}$

1) Berikan kesempatan seluas-luasnya kepada anakuntukmendapatkan keahlian dan pengetahuan yang mendalam.

2) Sediakan sebuah lingkungan atau situasi yang luar biasa bagi anak, di mana anak dapat menyatu dan bereksplorasi sesuai dengan minat dan bakatnya sehingga dapat dipastikan anak bisa menyelesaikan masalah yang sedang dihadapinya.

3) Memberikan petunjuk kepada anak dalam melihat suatu masalah, sehingga anak dapat mengembangkan kreativitas berpikir mereka untuk menyelesaikan masalah yang ada.

\section{Media yang dapat Mendukung Kreativitas Anak}

Seorang guru Taman Kanak-kanak selalu menginginkan agar pesan yang disampaikannya dapat diterima anak dengan efektif dan efisien. Untuk itu diperlukan media pembelajaran. Seperti kita ketahui bahwa peranan media pembelajaran dalam proses pembelajaran adalah sebagai penyalur pesan. Media yang dikembangkan dengan baik diharapkan dapat membantu anak memahami pesan yang disampaikan padanya. Waktu membuat media pembelajaran kita harus menentukan tujuan, yaitu bidang aspek mana pada anak yang ingin dikembangkan atau dicapai. Kita harus mempunyai gambaran yang jelas, dengan menggunakan media tersebut kemampuan apa yang kita harapkan akan dimiliki anak setelah proses pembelajaran. ${ }^{4}$

Setiap orang sangat menginginkan untuk menjadi orang yang sangat kreatif. Hendaknya potensi kreatif yang dimiliki manusia ini

${ }^{42}$ Indra Soefandi dan Ahmad pramudya, Strategi Mengembangkan Potensi Kecerdasan Anak, (Jakarta: Bee Media Indonesia, 2009), hlm 143-144.

${ }^{43}{ }^{I b i d}, . . . . h a l .145$.

${ }^{44}$ Badru Zaman, Media dan Sumber Belajar TK, (Jakarta: Universitas Terbuka, 2010), hal.53.

Jurnal Pelang̉i Jurnal pemikiran dan penelitian pendidkan Islam anak Usia Dini 
dipupuk sejak dini. Pada masa usia dini, individu memiliki peluang yang sangat besar untuk dapat mengembangkan potensinya tersebut. Banyak hal yang dapat difasilitas oleh kegiatan bermain ini, salah satu di antaranya adalah kreativitas anak memiliki potensi besar untuk menjadi jembatan terpeliharanya kreativitas dalam diri manusia selanjutnya. Berdasarkan hal tersebut di atas, maka berikut ini akan dikemukakan tujuh pengembangan kreativitas pada anak usia taman kanak-kanak antara lain;;5

Pertama, pengembangan kreativitas melalui menciptakan produk (Hasta Karya), pengembangan kreativitas pada anak melalui kegiatan hasta karya ini memiliki posisi penting dalam berbagai aspek perkembangan anak. Tidak hanya kreativitas yang akan terfasilitasi untuk berkembang dengan baik, tetapi juga kemampuan kognitif anak. Dalam kegiatan hasta karya setiap anak akan menggunakan imajinasinya untuk membentuk suatu bangunan atau benda tertentu sesuai dengan khyalannya.

Dalam pembuatannyapun mereka menggunakan berbagai bahan yang berbeda. Setiap anak bebas mengekspresikan kreativitasnya, sehingga kita akan memperoleh hasil yang berbeda antara satu anak dengan anaklainnya. Mungkinkita akan menemuianakyang membangun gedung pencakar langit dari toples kue, membuat terowongan dari dus, membuat rumah dari tanah liat dan sebagainya.

Kedua, pengembangan kreativitas melalui imajinasi, renungkan apa yang biasa kita lakukan semasa kanak-kanak, mungkin sebagian besar adalah yang biasa dilakukan anak yaitu berimajinasi. Ungkapan seperti "seandainya aku menjadi seorang astronot, atau seandainya aku bisa terbang dan tinggal di atas awan merupakan contoh dari imajinasi anak. Sebagai ilustrasi lain sebagian anak perempuan kerap kali melakukan sosiodarma dengan berpura-pura memasak, menyeterika, dan mencuci. Itu semua adalah sebuah contoh sederhana tentang dunia hayal anak yang biasa kita lihat sehari-hari. Salah satu latihan yang mendasar agar anak dapat memperagakan suatu situasi, memainkan peranannya dengan cara tertentu, memainkan peran seseorang dan menggantinya

\footnotetext{
${ }^{45}$ Yeni Rachmawati \& Euis Kurniaati, Strategi Pengembangan Kreativitas Pada Anak, (Jakarta: Kencana, 2011), hal.52.
} 
bila tidak cocok ataupun membayangkan suatu situasi yang tidak pernah mereka alami.

Ketiga, pengembangan kreativitas melalui eksplorasi, ide kreatif sering kali muncul dari eksplorasi atau penjelajahan individu terhadap sesuatu. Eksplorasi dapat memberikan kesempatan bagi anak untuk melihat, memahami, merasakan, dan pada akhirnya membuat sesuatu yang menarik perhatian mereka. Kegiatan seperti ini dilakukan dengan cara mengamati dunia sekitar sesuai dengan kenyataan yang ada secara langsung. Pengamatan tersebut bisa berupa lingkungan, di antranya hutan, bukit, pasir, laut, kolam, dan lingkungan alam lainnya.

Kegiatan yang dapat pengembangan kreativitas anak melalui eksplorasi ini dapat dilakukan dengan memanfaatkan lingkungan sekitar tempat tinggal anak, atau juga kegiatan-kegiatan yang memanfaatkan lingkungan sekitar tempat tinggal anak, atau juga kegiatan-kegiatan yang memanfaatkan lingkungan sekitar sebagai medianya misalnya, belajar pada alam sekitar (BALS), mediated learning experience, dan outbound training, salah satu upaya yang dapat kita lakukan untuk menstimulasi kreativitas anak usia dini adalah dengan memperkenalkan dan mengakrabkan mereka pada alam sekitarnya.

Keempat, pengembangan kreativitas melalui eksperimen, kegiatan eksperimen dapat pula dilakukan di taman kanak-kanak, melalui eksperimen anak akan terlatih mengembangkan kreativitas, kemampuan berpikir logis, senang mengamati, meningkatkan rasa ingin tahu dan kekaguman pada alam, ilmu pengetahuan dan tuhan. Melalui eksperimen sederhana anak akan menemukan hal ajaib dan menakjubkan. Hal ini penting, karena dengan rasa takjub dan kekaguman akan rahasiarahasia alam inilah anak akan tetap menyukai aktivitas belajar sampai tua. Melalui eksperimen pula anak dapat menemukan ide baru ataupun karya baru yang belum pernah mereka temui sebelumnya.

Kelima, pengembangan kreativitas melalui bahasa, sering kali kita menemukan anak-anak taman kanak-kanak berbicara. Memang sering berbicara tentang apa yang terjadi baik pada dirinya sendiri maupun orang lain. Mereka sering berbicara untuk mengeluarkan apa yang ada dalam pikiran mereka. Sikap ini mendorong meningkatkan penggunaan bahasa dan dialog dengan yang lain. Salah satu jalan bagi mereka untuk menggunakan bahasa adalah ekspresi perasaan. Sebagian anak

Jurnal Pelangi Jurnal pemikiran dan penelitian pendidkan Islam anak Usia Dini 
mengalami kesulitan mengngkapkan perasaan dengan kata-kata dan menunjukkannya dengan perbuatan, terkadang mereka lebih mudah mengekspresikan perasaan bonekanya sendiri daripada perasaan mereka sendiri. ${ }^{46}$

\section{Fungsi Pengembangan Kreativitas Untuk Anak Usia Dini}

Menurut B.E.F Montolalu pelaksanaan pengembangan kreativitas pada anak merupakan salah satu sarana belajar yang menunjang untuk mengembangkan beberapa aspek perkembangan anak. Fungsi pengembangan kreativitas pada anak TK adalah sebagai berikut;

Pertama, fungsi pengembangan kreativitas terhadap perkembangan kognitif anak. Melalui pengembangan kreativitas anak memperoleh kesempatan sepenuhnya untuk memenuhi kebutuhan berekspresi menurut caranya sendiri. Pemenuhan keinginan itu diperoleh anak dengan menciptakan sesuatu yang lain dan baru. Kegiatan yang menghasilkan sesuatu ini memupuk sikap anak untuk terus bersibuk diri dengan kegiatan kreatif yang akan mengacu perkembangan kognitif atau ketrampilan berfikirnya.

Kedua, fungsi pengembangan kreativitas terhadap kesehatan jiwa. Pengembangan kreativitas mempunyai nilai terapis karena dalam kegiatan berekspresi ini anak dapat menyalurkan perasaan-perasaan yang dapat menyebabkan ketegangan-ketegangan pada dirinya, seperti perasan sedih, kecewa, takut, khawatir dan lain-lain yang mungkin tidak dapat dikatakannya. Apabila perasan-perasaan tersebut tidak dapat disalurkan maka anak akan hidup dalam keteganganketegangan sehingga jiwanya akan tertekan. Hal ini akan menimbulkan penyimpangan-penyimpangan tingkah laku sehingga keseimbangan emosi anak akan terganggu.

Ketiga, fungsi pengembangan kreativitas terhadap perkembangan estetika. Disamping kegiatan-kegiatan berekspresi yang sifatnya mencipta, anak dibiasakan dan dilatih untuk menghayati bermacammacam keindahan seperti keindahan alam, lukisan, tarian, musik, dan sebagainya. Dengan kegiatan tersebut maka anak akan senantiasa menyerap pengaruh indah yang didengar, dilihat dan dihayatinya. Ini

${ }^{46} \mathrm{Ibid}, \ldots . . \mathrm{hal} .55$. 
berarti perasaan estetika atau perasaan keindahan anak terbina dan dikembangkan. Pada akhirnya anak akan memperoleh kecakapan untuk merasakan, membeda-bedakan, menghargai keindahan yang akan mengantar dan mempengaruhi kehalusan budi pekertinya. Dengan demikian, anak didekatkan pada sifat-sifat yang indah dan baik dalam kehidupannya sebagai manusia. ${ }^{47}$

\section{Peran Penggunaan Media Playdough/Plastisin Terhadap Kreativitas Anak}

Playdough/plastisin merupakan permainan yang dapat mengasah keterampilan, selain melatih motorik halus, pengenalan warna, bentuk, simbol, ukuran dan juga melatih kreativitas anak, playdough/plastisin juga termasuk mainan edukatif karena bisa mendorong imajinasi anak dan melatih jari-jemarinya, meskipun sebelumnya kita harus memberi contoh bagaimana kita membuat dan menggunakannya..

Mainan edukatif tidak selalu berarti mahal. Terkadang sesuatu yang bisa mencerdaskan anak bisa kita beli dengan harga murah atau bahkan bisa kita buat sendiri, playdough/plastisin salah satunya. Dengan playdough/plastisin anak bisa menciptakan berbagai bentuk sesuka hati mereka. Playdough/Plastisin merupakan material sehari-hari yang paling baik bagi anak untuk membuat anak senang, memberikan manfaat untuk melatih kreativits dan imajinasinya. ${ }^{48}$

\section{Hubungan antara Kreativitas dengan Playdough/Plastisin}

Playdough/plastisin dapat meningkatkan kecerdasan ruang dan gambar karena playdough/plastisin bisa membuat bentuk sesuai khayalan anak-anak. Menurut Teori Primary Mental Abilities yang dikemukakan oleh Thurstone dalam Yuliani Nurani Sujiono, bahwa kognitif merupakan penjelmaan dari kemampuan primer yang salah satunya adalah pemahaman ruang (spatial factors). ${ }^{49}$ Anak juga mampu memahami gambar berupa denah atau peta. Kecerdasan ini dapat mengembangkan kreatifitas anak untuk menciptakan pola-pola gambar

${ }^{47}$ Montolalu, B. E. F, Bermain dan Permainan Anak, (Jakarta: Universitas Terbuka, 2009), hal.28.

${ }^{48}$ Dorothy Einon, Creative Child (Anak Kreatif), (Jakarta: Pustaka Press, 2008), hal.43.

${ }^{49}$ Yuliani Nurani, \& Sujiono, Metode Pengembangan Kognitif, (Jakarta: Universitas Terbuka, 2008), hal.17.

Jurnal Pelangi Jurnal pemikiran dan penelitian pendidkan Islam anak Usia Dini 
yang baru. Apabila kecerdasan ruang dan gambar ini dikembangkan dan terasah dengan baik maka akan dapat membantu individu untuk menekuni berbagai profesi kerja di masa yang akan datang. Berbagai profesi kerja yang dapat ditekuni antara lain: arsitek, pemahat, pelukis, sutradara, perancang busana, perencanaan tata kota, insinyur tehnik sipil atau insinyur tehnik mesin, pilot, nahkoda. ${ }^{50}$

Ki Hajar Dewantara dalam Slamet Suyanto menyatakan bahwa Anak Usia Dini belajar paling baik dengan "Indra" (indranya). Dengan menyentuh, meremas, memukul, atau memegang playdough/plastisin anak akan dapat membuat berbagai bentuk apapun yang sering dijumpainya, bahkan mereka dapat memanipulasinya menjadi berbagai bentuk yang diinginkan. ${ }^{51}$

\section{METODE PENELITIAN}

Jenis penelitian ini adalah Penelitian Tindakan Kelas (Classroom Action Research). Penelitian Tindakan Kelas adalah proses investigasi terkendali untuk menemukan dan memecahkan masalah pembelajaran di kelas, proses pemecahan masalah itu dilakukan secara bersiklus dengan tujuan untuk meningkatkan kualitas proses dan hasil pembelajaran di kelas tertentu. ${ }^{52}$ Menurut McNiff seperti yang dikutip oleh Supardi memandang bahwa PTK sebagai bentuk penelitian reflektif yang dilakukan oleh pendidik terhadap kurikulum pengembangan sekolah, meningkatkan prestasi belajar, pengembangan keahlian mengajar, dan sebagainya. ${ }^{2}$ Metode yang digunakan dalam penelitian ini adalah penelitian tindakan kelas yang terdiri dari tiga siklus melalui langkah-langkah perencanaan, tindakan, observasi dan refleksi. Teknik pengumpulan data melalui observasi dan dokumentasi. Instrumen yang digunakan adalah lembar observasi (chek list). Teknik analisis data menggunakan trianggulasi. ${ }^{53}$

${ }^{50}$ Slamet Suyanto, Strategi Pendidikan Anak, (Yogyakatra: Hikayat, 2008), hal.5.

${ }^{51} \mathrm{Ibid}$, ....hal.11.

${ }^{52}$ Sa'dun Akbar, Penelitian Tindakan Kelas, (Filosofi, Metodologi, dan Implementasinya, (Malang: Surya Pena Gemilang, 2008), hal. 28

${ }^{53}$ Creswell, Research Design, Penelitian Kualitatif, dan Desain Riset., (Yogyakarta: Pustaka Pelajar , 2015) Edisi Ketiga (Terjemahan), hal.35. 


\section{HASIL PENELITIAN}

\section{Siklus I}

TK Bina Cerdas Desa Runggu adalah sebuah lembaga pendidikan yang berbasis Pendidikan Anak Usia Dini (PAUD) Salah satu visinya Terbentuknya Akhlak Mulia dalam kehidupan anak-anak TK Bina Cerdas secara kreatif dan sempurna. Banyak prestasi yang telah diukir oleh TK. Bina Cerdas s salah satunya adalah juara III karnaval sekecamatan Belo, juara II lomba Hafalan Ayat-ayat Pendek Al-Qur'an, harapan I lomba mewarnai Sekecamatan Belo. Disamping itu hampir 50 \% lulusan TK Bina Cerdas mendapat peringkat 10 besar dijenjang pendidikan sekolah dasar atau setingkat diatasnya yang tersebar di seluruh kecematan Belo. Sehingga Taman Kanak-Kanak ini memperoleh kepercayan penuh dari masyarakat sekitar.

Kepercayaan yang penuh dari masyarakat inilah yang membuat TK. Bina Cerdas berusaha menghadirkan yang terbaik dalam memberikan pelayanan terutama dalam bidang pendidikan yaitu proses pembelajaran. Sebagai akibatnya proses pembelajaran lebih mengedepankan pengembangan kemampuan akademik seperti membaca dan berhitung. Karena dengan anak bisa membaca dan berhitung orang tua merasa bangga dan tak merasa rugi menyekolahkan buah hatinya di Bina Cerdas Desa Runggu.

Pada umumnya anak mempunyai Kreativitas, akan tetapi kemampuan itu kurang mendapat perhatian sehingga tidak dapat berkembang secara optimal. Disamping itu upaya meningkatkan kreativitas anak kurang dilakukan oleh guru dalam proses pembelajaran. Pada hal melalui media Plastisin kreativitas anak dapat dikembangkan dan mengatasi rasa bosan akibat penggunanan metode yang statis dalam proses pembelajaran. Media Playdough juga dapat menghadirkan warna lain dalam proses kegiatan pembelajaran. untuk menindak lanjuti program penelitian ini maka peneliti menyusun program pelaksanaan yang terstruktur, yaitu:

\section{a. Perencanaan tindakan siklus I}

Kegiatan perencanaan ini dilaksanakan pada hari Rabu, tanggal 17 Oktober 2019 di TK Bina Cerdas Desa Runggu. Pada kesempatan tersebut, 
peneliti berdiskusi dengan kepala sekolah dan guru kelas terutama halhal yang akan dilakukan pada kegiatan pelaksanaan tindakan siklus I. Hal-hal yang diskusikan antara lain: (1) peneliti menyamakan persepsi dengan kepala sekolah dan guru kelas mengenai penelitian yang akan dilakukan, (2) peneliti mengusulkan penggunaan $\mathrm{m}$ e d i a . Playdough untuk pembelajaran peningkatan kreativitas, (3) peneliti mengusulkan perencanaan pembelajaran berupa SBP (Satuan Bidang Pengembangan) dan guru menyetujui, (4) peneliti mengusulkan observasi sebagai instrumen pokok penilaian pengembangan kreativitas, (5) menentukan jadwal pelaksanaan tindakan. Pada waktu diskusi disepakati bahwa peneliti sebagai pelaksana tindakan dan kepala sekolah serta guru kelas membantu selama proses pembelajaran dan sebagai observator. Alokasi waktu di setiap pertemuan selama 30 menit. Adapun tindakan dalam siklus pertama akan dilaksanakan dalam 3 kali pertemuan. Dimana pertemuan pertama pada hari Senin tanggal 22 Oktober 2019, pertemuan kedua pada hari Jum'at tanggal 2 November 2019, dan pertemuan ketiga pada hari Senin tanggal 5 November 2019.

Ada beberapa hal yang direncanakan pada siklus I, yaitu:

1) Peneliti mempersiapkan terlebih dahulu media yang akan digunakan yaitu Playdoug/Palstisin.

2) Peneliti mengkondisikan atau mensetting kelas menjadi lingkaran besar. Dimana peneliti sebagai pengajar dan kepala sekolah serta guru kelas sebagai pendamping dan observator.

3) Peneliti membuka pembelajaran dengan salam, do'a dan menyanyikan lagu selamat pagi.

4) Peneliti mengkomunikasikan aturan yang harus di patuhi selama kegiatan pengembangan kreativitas dengan media plyadough.

5) Peneliti menyampaikan materi tentang bentuk dan warna karakter yang akan di kreasikan, seperti membuat angka, huruf, atau benda benda lain.

6) Peneliti memulai memberikan contoh yang benar dalam membentuk benda dengan adonan yang diawali dengan membuat angka 1 dan huruf $\mathrm{A}^{\prime \prime}$. Dalam kegiatan ini peneliti dibantu oleh kepala sekolah dan guru kelas mengamati aktivitas anak selama mengikuti kegiatan pengembangan kreativitas rentang perhatian anak dalam menyimak 
peneliti saat membuat model contoh kreativitas, seperti huruf A dan angka 1 tadi, dan kemudian mencatatnya dalam pedoman observasi.

7) Peneliti mengulas penjelasan, dalam kegiatan ini peneliti memberi kesempatan pada anak untuk bereksplorasi. Peneliti mencoba merangsang anak dengan pertanyaan "Coba siapa yang tau apa yang bu guru buat...? siapa saja tokoh-tokoh yang ada dalam cerita, dan warna apa yang dihiasi dalam pembuatan contoh angka 1 dan huruf A.

8) Kegiatan penutup berupa reveiw/mengulang kembali penerapan pembuatan huruf A dan angka 1.

9) Peneliti menutup pembelajaran dengan lagu "yel-yel". Secara umum proses pembelajaran pada siklus I seperti yang tersebut di atas, akan tetapi pada tiap-tiap pertemuan peneliti memberi sedikit variasi dengan tujuan untuk memberikan pengalaman yang baru kepada anak serta agar anak didik tidak merasa bosan mengikuti pembelajaran pengembangan kreativitas.

Adapun variasi setiap pertemuan adalah sebagai berikut:

1). Pada pertemuan pertama peneliti menggunakan media Plastis in dengan pembuatan bentuk huruf dan angka. Kegiatan pada pertemuan pertama dilaksanakan didalam kelas.

2). Pada pertemuan kedua peneliti menggunakan media yang sama. Akan tetapi pada pertemuan kedua ini kegiatan pengembangan kreativitas ini dilaksanakan diluar kelas.

3). Pada pertemuan ketiga peneliti masih menggunakan media yang sama. Akan tetapi pada pertemuan ketiga ini kegiatan dilaksanakan didalam kelas kembali.

\section{b. Pelaksanaan Tindakan}

Sebagaimana yang telah direncanakan sebelumnya, tindakan pada siklus I dimulai pada hari Senin tanggal 22 oktober 2019. Pembelajaran ini berlangsung selama 30 menit yaitu dari pukul 07.30-08.00 dan berada di dalam maupun luar kelas TK. Bina Cerdas. Pada pertemuan pertama peneliti masuk ke dalam kelas yaitu kelas tampat anak-anak belajar.

Peneliti membuka kegiatan dengan tepuk spirit kemudian do'a, salam dan lagu Assalamu'alaikum. Adapun gambaran dialog yang terjadi antara anak dan peneliti adalah sebagai berikut: 
Peneliti : Selamat pagi teman-teman. Assalamu'alaikum wr wb. Anak-anak : Wa'alaikum salam wr.wb

Peneliti : Nah, teman-teman hari ini bu guru mau mengajar membuat benda dengan adonan. Siapa yang mau belajar membuat mainan?

Anak-anak : Saya...saya...saya, bu guru

Peneliti : Iya, teman-teman hebat semua, tapi ingat kalau mendengarkan penjelasan bu guru boleh tidaknya ramai sendiri?

Anak-ana : Tidak bu guru.

Peneliti : Berarti nanti teman-teman harus tenang dan tidak boleh ramai sendiri. Apakah siap?

Anak-anak : Siap.

Setelah memberikan penjelasan di kelas, peneliti yang didampingi kepala sekolah dan guru kelas mengkondisikan tempat duduk anak menjadi lingkaran besar dimana peneliti sebagai pusat lingkaran. Hal ini bertujuan untuk menciptakan suasana belajar yang aman dan nyaman serta terjalin komunikasi multiarah dan anak-anak bisa melihat buku cerita tanpa merasa terhalang sehingga proses pembuatan contoh benda hasil kreativitas dapat dilihat anak secara keseluruhan.

Sebagai pembuka peneliti yang bertindak sebagai guru membuka kegiatan dengan salam, bernyanyi, dan berdo'a. Sebelum bercerita peneliti menyebutkan benda apa yang mau dikreasikan seperti huruf dan angka. Selanjutnya peneliti memulai membentuk sebuah benda dengan media Playdough. Setelah guru selesai membentuk benda model Huruf B dan angka 2, guru menjelaskan kembali tentang apa yang dibentuk. Dalam kegiatan penjelasan ini, peneliti memberi kebebasan terhadap anak untuk berekspresi mengungkapkan idenya dalam membentuk benda dengan media playdough. Dari kegiatan ini peneliti, kepala sekolah dan guru kelas dapat melihat kreativitas anak yang ditunjukan dalam sikap kreatifnya. Anak-anak mengajukan pertanyaan seputar benda yang dibuat yang dalam hal ini salah satu reaksi anak diantaranya adalah "bisa gak kita buat dinosaurus bu..? Saya bisa membikinnya bu.... ! kata Syarif. Pada saat inilah anak mengalami proses perkembangan dimana anak mulai mengkreasikan wacana dan idenya sendiri tentang benda yang ingin dibuatnya. Disamping itu peneliti juga dapat melihat rentang 
perhatiaan anak selama peneliti menyampaikan penjelasan. Peneliti juga dapat melihat anak-anak memperoleh ide baru yang belum pernah mereka lihat sebelumnya seperti seperti keinginan yang disampaikan Syarif, "aku juga ingin membuat bebek kata Udin, " Aku ingin membuat Bulan aja bu guru kata Vina". Karena Anak-anak yang pintar tidak akan takut atau ragu dalam menunjukan kepercayaan diri untuk mencoba mengembangkan ide dan pemikiranya. Diakhir pembelajaran peneliti melakukan reveiw, mengajukan pertanyaan seputar pembuatan benda dengan playdough. Hal ini bertujuan untuk mengetahui sejauh mana perkembangan anak terhadap kreativitas media playdough yang disampaikan peneliti atau guru. Dalam proses tersebut kolaborator kepala sekolah dan guru kelas mencatat kreativitas anak seperti yang ditunjukan dalam ciri-ciri anak kreatif selama mengikuti kegiatan.

Paparan tersebut di atas merupakan proses pembelajaran pada siklus I pertemuan pertama. Sebagaimana yang telah direncanakan, secara garis besar proses pembelajaran seperti yang telah disebutkan di atas. Pada setiap pertemuan peneliti dan guru sepakat untuk memberikan variasi agar anak-anak tidak merasa bosan dan suasana kelas lebih menyenangkan. Pada pertemuan kedua yakni dilaksanakan pada hari Rabu tanggal 2 November 2019, peneliti mencoba memvariasikan suasana kelas dengan melakukan kegiatan bercerita diluar kelas atau alam terbuka. Anak-anak sangat antusias mengikuti kegiatan diluar kelas atau alam terbuka. Suasana pembelajaran menjadi lebih kondusif, anak lebih aktif berkreativ anakpun juga mengalami peningkatan dari $13.33 \%$ atau 6 anak mencapai $23.33 \%$ atau 15 anak.

Untuk pertemuan ketiga berdasarkan kesepakatan dilaksanakan pada hari jum'at tanggal 4 juni 2019. Pada pertemuan ketiga ini kegiatan bercerita kembali dilakukan didalam kelas. Antusias anak dalam mengikuti kegiatan bercerita pada pertemuan ketiga ini tidak menunjukan peningkatan kemampuan yang siknifikan. Hal ini dapat terlihat dari peningkatan kreativitas dimana pada pertemuan kedua mencapai $23.33 \%$ atau 15 anak sedangkan pada pertemuan ketiga sebesar $46.67 \%$ atau 21 anak.

\section{c. Observasi}

Observasi dilakukan pada saat kegiatan pembelajaran khususnya

Jurnal Pelang̉i Jurnal pemikiran dan penelitian pendidkan Islam anak Usia Dini 
di ruang kepala sekolah. Observasi dilakukan untuk mengetahui peningkatan kreativitas anak selama mengikuti kegiatan bercerita. Berdasarkan pengamatan yang dilakukan peneliti, kepala sekolah dan guru kelas, diperoleh hasil sebagai berikut: (1) pada pertemuan pertama anak-anak masih merasa asing dengan proses pembelajaran dengan menggunakan media buku cerita bergambar, (2) pada pertemuan kedua anak-anak sangat antusias mengikuti pembelajaran dengan menggunakan media buku cerita bergambar, (3) pada pertemuan ketiga anak-anak mulai merasa bosan terhadap proses pembelajaran karena penggunaan media dengan judul yang sama, (4) konsentrasi anak terhadap cerita mengalami penurunan karena tidak adanya motivasi atau rewads untuk anak atas kreativitasnya, (5) terjadi peningkatan kreativitas yaitu sebelum penelitian anak-anak yang menunjukan sikap kreatif hanya sebesar $8.33 \%$ atau 4 anak, pada pertemuan pertama mencapai $20.83 \%$ atau 10 anak, pertemuan kedua mencapai $31.25 \%$ atau 15 anak, dan pertemuan ketiga mencapai $47.82 \%$ atau 22 anak.

\section{d. Analisis dan Refleksi}

Berdasarkan hasil observasi tersebut, peneliti dan guru melakukan analisis terhadap proses pembelajaran dan peningkatan kemampuan berbicara anak usia dini. Analisis ini dilakukan oleh kepala sekolah, guru kelas dan peneliti dengan cara berdiskusi, mengevaluasi proses pembelajaran yang telah dilalui, serta melihat kekurangan-kekurangan yang ada. Selain itu kepala sekolah, guru dan peneliti juga berpedoman pada hasil observasi peningkatan kreativitas anak melalui pedoman observasi.

Adapun hasil analisis tersebut menunjukkan bahwa: (1) adanya reaksi yang menunjukan kebosanan pada anak karena penggunaan media dengan model pembuatan benda yang sama, (2) adanya penurunan konsentrasi karena tidak adanya motivasi atau rewads dari peneliti atas kemampuannya, (3) sudah ada perkembangan kreativitas anak jika dibandingkan dengan kreativitas sebelum tindakan, akan tetapi hasil tersebut belum maksimal dan memuaskan, itu berarti bahwa peneliti dan guru perlu memperbaiki proses pembelajaran, (4) peningkatan didik dalam satu kelas masih belum merata, ada anak yang mempunyai kemampuan lebih akan tetapi ada yang juga yang masih rendah. 
Dari hasil analisis tersebut peneliti dan guru merasa bahwa hasil penelitian ini belum maksimal. Oleh sebab itu peneliti dan guru membuat perencanaan untuk tindakan pada siklus berikutnya.

\section{Tindakan Kelas Siklus II}

\section{a. Perancanaan tindakan kelas siklus II}

Proses pengembangan kretivitas anak melalui media playdough yang telah dilakukan pada siklus I pada umumnya sudah cukup baik, tetapi belum memuaskan. Masih ada anak yang kurang memperhatikan dan peningkatan kemampuan juga kurang memuaskan. Untuk mengatasi kekurangan pada siklus I, maka pada hari Sabtu tanggal 10 Desember 2019 peneliti, kepala sekolah, dan guru merencanakan tindakan pada siklus II. Siklus II ini direncanakan dilakukan dalam 2 pertemuan yaitu pertemuan pertama pada hari Selasa tanggal 13 Desember 2019, dan pertemuan kedua pada hari Selasa tanggal 20 Desember 2019. Setelah melakukan diskusi, akhirnya peneliti, kepala sekolah, dan guru kelas menyepakati beberapa hal yang sebaiknya dilakukan dalam pengembangan kreativitas anak. Hal-hal tersebut yaitu: (1) peneliti memaksimalkan tindakan yaitu lebih berinteraksi dengan anak didik, memberikan motivasi dan memberi penguatan berupa rewads seperti "Sempurna", (2) untuk mengatasi kebosanan anak terhadap satu model kreativitas maka peneliti, kepala sekolah dan guru berencana untuk mengganti model/bentuk kreasi yang sebelumnya hanya berbentuk angka dan huruf, (3) peneliti memberi tambahan alokasi waktu agar anak mempunyai banya waktu untuk bereksplorasi.

Adapun urutan tindakan yang direncanakan diterapkan pada siklus II adalah sebagai berikut:

1). Peneliti mempersiapkan terlebih dahulu media yang akan digunakan yaitu media playdough/plastisin.

2). Peneliti mengkondisikan atau mensetting kelas menjadi lingkaran besar. Dimana peneliti sebagai pencerita dan kepala sekolah serta guru kelas sebagai pendamping dan observator.

3). Peneliti membuka pembelajaran dengan salam, do'a dan menyanyikan lagu selamat pagi.

4). Peneliti mengkomunikasikan aturan yang harus di patuhi 
selama kegiatan bercerita.

5). Peneliti menyebutkan judul dan model pembuatan kreasi dengan Playdoug/Plastisin, tokoh-tokoh yang ada dalam cerita.

6). Peneliti memulai membuat contoh kreativitas dengan model dan bentuk karakter binatang, seperti. Kucing dan Gajah Dalam kegiatan ini peneliti dibantu oleh kepala sekolah dan guru kelas mengamati aktivitas anak selama mengikuti kegiatan pengembangan kreativitas dan kemudian mencatatnya dalam pedoman observasi.

7). Peneliti mengulas kembali tentang cara dan proses pembuatan model kreasi (Kucing dan Gajah). Selama kegiatan ini peneliti mengamati reaksi anak terhadap materi tentang cara membentuk Playdough dengan karakter kucing dan gajah yang disampaikan oleh peneliti seperti reaksi mengajukan ide untuk dibuatkan contoh dan model lain yang lebih menarik bagi anak dan sesekali mereka mengajukan diri untuk mencoba sendiri dalam berkreasi adonan menjadi robot, maupun karakter lainnya, meskipun dalam upaya percobaan yang mereka lakukan, namun kepercayaan diri dalam membawakan cerita, imajinasi anak terhadap mengkreasikan ide dan gagasan harus dinilai sebagai kemajuan/perkembangan yang lumayan baik.

8). Kegiatan penutup berupa reveiw/ mengulang kembali tentang apa yang dibuat atau dikreasikan sebelumnya.

9). Peneliti menutup pembelajaran dengan lagu "Aku Anak Sehat". Secara umum prosedur pembelajaran pada siklus II seperti tersebut di atas. Sama seperti proses pembelajaran pada siklus I, setiap pertemuan pada siklus II inijuga diberi sedikit variasi agar anak tidak mengalami kebosanan dan suasana lebih menyenangkan. Adapun variasi setiap pertemuan yaitu kegiatan dilakukan diluar dan dalam kelas, mengganti karakter kreatifitas yang sebelumnya pada siklus I hanya dalam bentuk angka dan huruf, memberi motivasi/rewads pada anak agar dapat mengembangkan kemampuannya, konsentrasi atau rentang perhatian anak terhadap kegiatan menjadi lebih lama, merangsang anak dengan pertanyan-pertanyaan seputar karakter benda yang dibuat sehingga anak dapat menemukan kosakata baru yang didapat dari jawaban-jawabannya, dan berkembang imajinasinya sehingga dapat menghasilkan kreativitas 
yang alami serta kepercayaan diri anak makin kuat.

\section{b. Pelaksanaan Tindakan}

Berdasarkan perencanaan yang telah dibuat, maka peneliti, kepala sekolah, dan guru kelas melaksanakan pada siklus II. Pelaksanaan tindakan pada siklus II dimulai pada hari Selasa 27 Desember 2019 di luar kelas TK. Bina Cerdas. Pembelajaran berlangsung selama 45 menit yaitu pukul 07.30-08.15 dan dilaksanakan diluar kelas. Pada pertemuan pertama peneliti mengajak anak-anak kealam terbuka yaitu halaman TK. Bina cerdas. Peneliti membuka kegiatan dengan tepuk spirit kemudian do'a, salam dan lagu Selamat pagi.

Adapun gambaran dialog antara peneliti dengan anak adalah sebagai berikut:

Peneliti : Selamat pagi anak-anak, selamat pagi dan apa kabar semuanya?

Anak : Selamat pagi bu guru, kabar baik...

Peneliti : Hari ini bu guru akan mengajarkan tentang membuat mainan. Nah, kira-kira mainan apa ya,,,?

Anak : Mobil-mobilan bu.?, Rumah-rumahan bu..?

Peneliti : Oke, sekarang siapa yang mau dengarkan ajaran bu guru?

Anak : saya...saya....saya.

Peneliti : Duduklah yang manis.

Setelah memberikan penjelasan diluar kelas, peneliti yang didampingi kepala sekolah dan guru kelas mengkondisikan tempat duduk anak membentuk lingkaran dimana peneliti sebagai pusat lingkaran. Hal ini bertujuan untuk menciptakan suasana belajar yang aman dan nyaman serta terjalin komunikasi dengan anak-anak tanpa merasa terhalang sehingga anak bisa membuat berbagai macam bentuk dengan menggunakan plastisin.

Pada pertemuan pertama peneliti menggunakan media Playdough untuk membuat benda dengan Playdough yang berbentu alat perabot rumah tangga seperti, meja, kursi dan lain-lainya". Antusias anak terhadap pelajaran sangat baik. Anak-anak sangat konsen dalam menyimak pengajaran dari peneliti dan sekali terjadi kelucuan didalamnya seperti bu guru, bu guru minta ayam gorengnya dong? "rayu Hidayatullah". Bu guru, bu guru kemarin aku makan permen tapi gigiku tidak sakit," cerita Ardi". 
Pada pertemuan kedua kegiatan dilakukan didalam kelas. Pada pertemuan kedua peneliti menggunakan media yang sama yaitu media Playdough dengan karakter benda perabotan rumah tangga seperti meja, kursi dan lain-lainnya". perhatian anak terhadap pelajaran masih sangat baik, anak makin lebih antusias untuk tampil didepan kelas sambil menunjukkan hasil kreasi mereka sendiri sesuai dengan gaya yang mereka miliki. Antusias anak makin bertamabah ketika peneliti menggunakan rewads "Sempurna", anak makin terlibat aktif dalam proses pembelajaran. Konsetrasi anak terhadap pelajaran makin bertambah, ide dan kreasi yang dimiliki anak semakin banyak, imajinasi anak makin berkembang, keberanian untuk tampil didepan kelas tidak lagi menunggu perintah peneliti, kemampuan anak dalam membentuk adonan semakin mahir. Anak-anak berlomba-lomba untuk mendapat rewads dari peneliti.

\section{c. Observasi}

Kegiatan observasi dilakukan pada saat kegiatan pembelajaran diruang kepala sekolah. Pada siklus II ini peneliti dan dibantu oleh kolaborator melakukan pengamatan terhadap peningkatan kreativitas dan keaktifan anak dalam mengikuti pembelajaran. Observasi dilakukan untuk membandingkan perkembangan kreativitas anak antara siklus I dengan siklus II. Seperti pada siklus I, observasi difokuskan pada pemberian motivasi pada anak untuk berani bereksplorasi dan menumbuhkan kepercayaan diri untuk tampil didepan kelas sambil menunjukkan kreativitas mereka.

Berdasarkan hasil pengamatan yang dilakukan oleh peneliti dan guru maka diperoleh hasil sebagai berikut: (1) setelah diajarkan membentuk benda dengan adonan dalam bentuk, model, dan karakter yang berbeda, anak menjadi lebih antusias dalam menunjukkan ketrampilannya, (2) setelah diberikan motivasi, anak-anak menjadi aktif untuk tampil didepan kelas sambil menampilkan hasil kreativitas mereka tanpa menunggu perintah dari peneliti, (4) terjadi perkembangan kemampuan yang sangat memuaskan pada siklus II ini yaitu pada siklus I pertemuan ketiga kreativitas anak sebesar $47.82 \%$ atau 22 anak sedangkan pada siklus II pertemuan pertama sebesar $62.50 \%$ atau 30 anak dan pada pertemuan kedua telah mencapai $79.17 \%$ atau 38 anak. 


\section{d. Analisis dan Refleksi}

Proses pelaksanaan tindakan pada siklus II sudah baik. Kelemahan yang ada pada siklus I dapat teratasi dengan baik. Hal ini menunjukan pengembangan krativitas anak melalui media Playdough mengalami peningkatan. Peningkatan kemampuan berbicara ini terlihat dari tercapainya indikator yang ditetapkan, seperti peningkatan kreativitas anak yang mencapai $79.17 \%$, kreativitas anak yang meningkat serta perhatian dan konsentrasi anak dalam pembelajaranpun membaik. Peneliti dengan dibantu kolaborator telah berhasil meningkatkan kemampuan anak serta perhatian dan konsentrasi anak dalam proses pembelajaran.

Adapun masih ditemukannya satu atau dua anak yang kurang memperhatikan peneliti tidak menjadi masalah dalam proses pembelajaran, karena kita tahu bahwa karakteristik, kemampuan, dan daya tangkap anak didik itu beraneka ragam. kreativitas anak pada TK. Bina Cerdas semester I tahun pelajaran 2018/2019 telah mengalami peningkatan sebesar $79.17 \%$ atau 38 anak dari 48 anak.

\section{Pemba}

Sebelum pembahasan hasil penelitian, adapun proses dan hasil penelitian secara keseluruhan dapat dilihat dalam tabel berikut:

\begin{tabular}{|l|l|l|}
\hline \multicolumn{1}{|c|}{ Aspek } & \multicolumn{1}{c|}{ Siklus I } & \multicolumn{1}{c|}{ Siklus II } \\
\hline $\begin{array}{l}\text { Media yang } \\
\text { digunakan }\end{array}$ & Playdough/Plastisin & Playdough/Plastisin \\
\hline $\begin{array}{l}\text { Indikator } \\
\text { Kreatifitas }\end{array}$ & & \\
\hline $\begin{array}{l}\text { Proses } \\
\text { Pembelajaran }\end{array}$ & $\begin{array}{l}\bullet \text { Pembukaan } \\
\text { Inti } \\
\text { Penutup }\end{array}$ & $\begin{array}{l}\bullet \text { Pembukaan } \\
\text { Inti }\end{array}$ \\
\hline $\begin{array}{l}\text { Waktu Penutup } \\
\text { Pembelajaran }\end{array}$ & 30 Menit & 45 Menit \\
\hline
\end{tabular}

Jurnal Pelang̉i Jurnal pemikiran dan penelitian pendidkan Islam anak Usia Dini 


\begin{tabular}{|l|l|l|}
\hline \multicolumn{1}{|c|}{ Aspek } & \multicolumn{1}{|c|}{ Siklus I } & \multicolumn{1}{c|}{ Siklus II } \\
\hline Observasi & $\begin{array}{l}\text { Pertemuan pertama } \\
\text { anak masih asing } \\
\text { dengan pembelajaran } \\
\text { yang diberikan, } \\
\text { pertemuan kedua } \\
\text { antusias anak dalam } \\
\text { pembelajaran sudah } \\
\text { baik, petemuan ketiga } \\
\text { anak merasa bosan } \\
\text { terhadap proses } \\
\text { pembelajaran. }\end{array}$ & $\begin{array}{l}\text { Pertemuan pertama anak } \\
\text { sangat antusias terhadap proses } \\
\text { pembelajaran, pertemuan kedua } \\
\text { antusias anak masih sangat baik, } \\
\text { anak-anak berlomba-lomba untuk } \\
\text { tampil di depan kelas. }\end{array}$ \\
\hline $\begin{array}{l}\text { Analisis dan } \\
\text { Refleksi }\end{array}$ & $\begin{array}{l}\text { Antusias anak } \\
\text { berkurang karena } \\
\text { anak merasa bosan } \\
\text { terhadap penggunaan } \\
\text { media yang sama }\end{array}$ & $\begin{array}{l}\text { Antusias anak } \\
\text { bertambah karena } \\
\text { adanya motivasi } \\
\text { berupa rewards } \\
\text { Sangat Bagus }\end{array}$ \\
\hline Kreativitas & 62.50\% & 79.17\% \\
\hline
\end{tabular}

Table 4.1. peningkatan kreativitas

Berdasarkan tabel tersebut dapat di ketahui bahwa kreativitas sebelum tindakan sampai dengan siklus ke II menunjukkan peningkatan. siklus I sebesar $62.50 \%$, siklus II mencapai $79.17 \%$. Berdasarkan analisis yang di lakukan oleh peneliti hal ini pengembangan kreativita anak di pengaruhi oleh media yakni Playdough/Plastisin. Melalui Playdough anak dapat mengembangkan ide, mengajukan tawaran untuk membuat model benda yang lain yang kemudian menemukan ketrampilan ( reaksi kreatif) terhadap penjelasan yang mereka dengar, rentang perhatian anak terhadap cerita menjadi lebih panjang karena anak berkonsentrasi terhadap penjelasan anak juga mampu mengorganisasikan kemampuan diri karena anak belajar dari pengalaman yang menabjubkan sehingga akan membangun kepercayaan diri terhadap apa yang disampaikan. Selain itu melalui kreativitas anak memperoleh ide untuk memikirkan kreasi baru, imajinasi anak pun dapat berkembang dan dari imajinasinyaitu merupakan awal dari anak mengaitkan ide sehingga akan menghasilkan karya yang original sebagai bekal anak untuk menjadi pengrajin yang alami. Hal ini juga di dukung dan sesuai dengan pendapat yang dikemukakan oleh Paul Torrance yang menyebutkan bahwa karakteristik tindakan kreatif adalah 
(1) anak kreatif belajar dengan cara-cara yang kreatif seperti anak belajar mengajukan pertanyaan, menebak-nebak yang kemudian menemukan jawaban, (2) anak kreatif belajar memiliki rentang perhatian yang panjang terhadap hal yang menunjukan usaha kreatif seperti mendengarkan cerita (3) anak kreatif memiliki kepampuan mengorganisasikan yang menajubkan karena anak kreatif akan merasa lebih dari orang lain sehingga kepercayan diri anak untuk tampil didepan sangat tinggi, (4) anak kreatif dapat kembali kepada sesuatu yang sudah dikenalnya dan melihat dari cara yang berbeda. Melalui pelajaran pengembangan kreativitas anak akan belajar mengaitkan ide-ide sehingga menghasilkan karya yang original. Dengan bekal ini anak akan terbentuk menjadi sosok pengrajin yang alami, (5) anak kreatif belajar banyak melalui fantasi, dan memecahkan permasalahannya dengan menggunakan pengalamannya. Hal ini dapat terlihat ketika anak mendengarkan penjelasan dan demonstrasi guru saat memngajarkan, anak akan berimajinasi tentang penjelasan yang mereka dengar yang kemudian imajinasi tersebut dapat digunakan sebagi pengembangan kreativitas yang mereka miliki, (6) anak kreatif menikmati permainan dengan alat peraga dan tempat sebagai latihan yang alami. Dengan melihat playdough anak akan sering mendapatkan ide-ide baru yang pada akhirnya pengalaman itu dipakai untuk mengespresikan ideide kreatifnya. Selain dipengaruhi oleh media Playdough keberhasilan peningkatan kemampuan kreativitas anak ini juga dipengaruhi oleh metode pendukung yang berupa pemberian kesempatan pada anak untuk tampil didepan kelas mengekspresikan kemampuan berkreasi yang dimiliki. Adapun peningkatan kreativitas di setiap siklus tidak menunjukkan suatu kestabilan. Dimana prosentase peningkatan sebelum tindakan sampai dengan siklus I mencapai $16.67 \%$. Dari siklus I sampai siklus II peningkatan sebesar $16.67 \%$. Disini diketahui bahwa sebelum tindakan sampai siklus I mengalami peningkatan yang cukup signifikan, hal ini disebabkan karena pada awal-awal pertemuan ketertarikan anak masih sangat tinggi, mereka sangat semangat dan antusias terhadap hal baru yang belum pernah ia dapatkan.

Adapun untuk peningkatan dari siklus I ke siklus II juga mengalami peningkatan yang cukup memuaskan, hal ini sebabkan karena adanya pemberian motivasi selama pelaksanaan siklus II. Sehingga anak cukup antusias dalam mengikuti pembelajaran.

Jurnal Pelang̉i Jurnal pemikiran dan penelitian pendidkan Islam anak Usia Dini 


\section{KESIMPULAN}

Berdasarkan hasil temuan dilapangan tentang Penggunaan Media Playdough/Plastisin Untuk Mengembangkan Kreativitas Anak Usia 4-5 Tahun di TK Bina Cerdas Desa Runggu Kecamatan Belo. Dalam pengajaran guru memberikan motivasi, semangat, pujian-pujian. Kemudian, memberikan perhatian lebih, agar dapat merasakan bakat yang ada dalam diri anak tersebut aktif, dan berani tampil.

Faktor penghambat dalam mengembangkan kreativitas pada Anak Usia Dini di TK Bina Cerdas Kecamatan Belo Kabupaten Bima. Sebagai orangtua terlalu memaksa anak untuk melakukan hal tersebut, sehingga anak tersebut bosan dan mau mengikuti perintah orangtuanya. Selanjutnya orangtua terlalu memaksa anak mendapatkan juara, sehingga anak merasa tertekan. Selain itu juga guru yang tidak paham terhadap kemauan anak, sehingga anak tidak menuruti apa yang di suruh oleh gurunya.

\section{DAFTAR PUSTAKA}

Abuddin Nata, 2014, Perspektif Islam Tentang Strategi Pembelajaran, Jakarta:Charisma Putra Utama Cetakan ke 3.

Akbar Sa'dun, 2008, Penelitian Tindakan Kelas, (Filosofi, Metodologi, dan Implementasinya, Malang: Surya Pena Gemilang.

Arsyad Azhar, 2014, Media Pembelajaran, Bandung: PT Rosdakarya.

Auryn Virzara, 2007, How to Create a Smart Kinds: Cara Praktis Menciptakan Anak Sehat dan Cerdas, Yogjakarta: Ar Ruzz Media Group.

Chintia Monica, 2015, Buku Kreativitas Anak, Jakarta: Bintang Indonesia.

Creswell, Research Design, Penelitian Kualitatif, dan Desain Riset, Yogyakarta:

Pustaka Pelajar, 2015, Edisi Ketiga Terjemahan.

Dalyono M, 2007, Psikologi Pendidikan, Jakarta: PT Rineka Cipta.

Departemen Pendidikan Nasional, 2005, Kamus Besar Bahasa Indonesia; Edisi Ketiga, Jakarta: Balai Pustaka.

Dwijunianto, Media Belajar Plastisin, http://dwijunianto.wordpress.com/ mediabelajar-plastisin, diakses pada hari rabu tanggal 11bulan 10 tahun 2017 jam 12:20 WIB.

Dwirosanty, Bikin Playdough Sendiri, www.associatedcontent.com/article., 
diakses pada hari kamis tanggal 12 bulan 10 tahun 2017 jam 12:00 WIB.

Dwirosanty, Manfaat Playdough, www.associatedcontent.com/article, diakses pada hari kamis tanggal 12 bulan 10 tahun 2017 jam 12:00 WIB.

Einon Dorothy, 2008, Creative Child (Anak Kreatif), Jakarta: Pustaka Press. Einon Dorothy, 2008, Creative Child (Anak Kreatif), Jakarta: Pustaka Press. Einon Dorothy, 2008, Creative Child (Anak Kreatif), Jakarta: Pustaka Press. F. E. B, Montolalu, 2009, Bermain dan Permainan Anak, Jakarta: Universitas Terbuka.

F.E. B Montolalu, 2009, Bermain dan Permainan Anak, Jakarta: Universitas Terbuka.

Fadlillah Muhammad, 2012, Desain Pembelajaran Paud Tinjauan Teoritik dan Praktik, Yogyakarta:Ar-Ruzz Media, cetakan 1.

Jamaris Martini, 2006, Perkembangan dan Pengembangan Anak Usia Taman

Kanak-kanak, Jakarta: PT Gramedia Widiasarana Indonesia.

Jatmika Nur ,Yusep, 2012, Ragam Aktivitas Harian untuk Playgroup, Yogyakarta: DIVA Press.

Maryani Eni, 2011, Media dan Perubahan Sosial, Bandung: Rosdakarya, Cet Ke-1.

Munandar Utami, 2004, Pengembangan Kreativitas Anak Berbakat Jakarta: PT. Rineka Cipta.

Musthofa Aziz, 2009, Aku Anak Hebat Bukan Anak Nakal, Jogjakarta: Diva Press.

Naim Ngainum, 2009, Menjadi Guru Inspiratif, Yogyakarta: Pustaka Pelajar.

Nurani Yuliani, \& Sujiono, 2008, Metode Pengembangan Kognitif, Jakarta: Universitas Terbuka.

Nursisto, 1999, Kiat Menggali Kreativitas, Yogyakarta: Mitra Gama Widya. Pujianto, Media Belajar Plastisin, http://dwijunianto.wordpress.com/ mediabelajar-plastisin, diakses pada hari rabu tanggal 11bulan 10 tahun 2017 jam 11:25 WIB.

Rachmawati Yeni \& Kurniaati Euis, 2011, Strategi Pengembangan Kreativitas Pada Anak, Jakarta: Kencana.

Rachmawati Yeni \& Kurniati Euis, 2014, Strategi Pengembangan Kreativitas Pada Anak Usia Taman Kanak-Kanak, Yogyakarta: Gremedia Pustaka.

Jurnal Pelang̉i Jurnal pemikiran dan penelitian pendidkan Islam anak Usia Dini 
Sanjaya Wina, 2010, Strategi Pembelajaran Berorientasi Standar Proses Pendidikan, Jakarta: Prenada Media Group.

Sayogya Tut, 2008, Creative Mind, Jakarta: Elex Media Komputindo. Slamet Suyanto, 2008, Strategi Pendidikan Anak, Yogyakatra: Hikayat.

Slameto, 2003, Belajar dan Faktor-faktor yang Mempengaruhinya, Jakarta: PT Rineka Cipta.

Soefandi Indra \& Pramudya Ahmad, 2009, Strategi Mengembangkan Potensi Kecerdasan Anak, Jakarta: Bee Media Indonesia.

Soefandi Indra, dan Pramudya Ahmad S, 2009, Strategi Mengembangkan Potensi Kecerdasan Anak, Jakarta:Bee Media Indonesia.

Sumanto, 2005, Pengembangan Kreativitas Seni Rupa Anak TK, Jakarta: Diretur Pembinaan Pendidikan Tenaga Kependidikan dan Ketenagaan Perguruan Tinggi.

Supardi 2009, Belajar Dengan Lilin Plastin, Http://BK2009.Wordpress.

Com/2010/11/30/ Belajar-dengan- Lilin-Plastisinkel, diakses pada hari rabu tanggal 11 bulan 10 tahun 2017 jam 12:25 WIB.

Susanto Ahmad, 2011, Perkembangan Anak Usia Dini Pengantar dalam Berbagai Aspeknya, (Jakarta: Kencana.

Syakira Fadia, 2015, Cara Membuat Playdough dengan Mudah, Bandung: Rosdakarya.

Taufan, Permainan Playdough, www.albalitacerdas.com., diakses pada hari kamis Tanggal 12 bulan 10 tahun 2017, jam 12:02 WIB.

Utami Munandar, 2014, Mengembangkan Bakat Dan Kreativitas Anak Sekolah Petunjuk Bagi Para Guru dan Orangtua, Jakarta: Grasindo.

Utami Munandar, 2015, Pengembangan Kreativitas Anak Berbakat, Bandung: PT. Rosdakarya.

Well Mina, Membuat Plastisin yang Menyenangkan Sejarah Clay, http:// wwww. scribd. com/dok/80089975/plastisin, diakses pada hari kamis tanggal 12 bulan 10 tahun 2017 jam 12:12 WIB

Yuliani Nurani Sujiono, dkk, 2010, Bermain Kreatif Berbasisi Kecerdasan Jamak, Jakarta: PT Indeks.

Zaman Badru, 2010, Media dan Sumber Belajar TK, Jakarta: Universitas Terbuka. 